\title{
Diferensial Granulosit Sapi Bali di Dataran Tinggi dan Rendah di Nusa Penida
}

\author{
(GRANULOCYTES DIFFERENTIAL OF BALI CATTLE IN THE DIFFERENT HIGHER \\ AT NUSA PENIDA)
}

\author{
Ni Made Riska Adnyani' ${ }^{1}$, Ni Ketut Suwiti², Ni Luh Eka Setiasih ${ }^{2}$ \\ ${ }^{1}$ Praktisi Dokter Hewan di Kabupaten Badung \\ ${ }^{2}$ Laboratorium Histologi Veteriner Universitas Udayana \\ Jln. PB. Sudirman Denpasar-Bali \\ Email: riska.adnyani@yahoo.co.id
}

\begin{abstract}
ABSTRAK
Penelitian ini bertujuan untuk mengetahui diferensial granulosit terhadap neutrofil, eosinofil, dan basofil sapi bali yang diternakkan di dataran tinggi dan rendah Nusa Penida. Sampel yang digunakan adalah darah 60 ekor sapi bali betina. Pengambilan sampel darah sapi bali dilakukan secara random dengan tekhnik multi-stage sampling. Pengambilan darah dilakukan melalui vena jugularis menggunakan venoject. Pembuatan apusan darah menggunakan metode slide yang dilanjutkan dengan fiksasi dan pewarnaan Giemsa. Penghitungan diferensial leukosit menggunakan metode Battlement hingga ditemukan 100 sel leukosit dengan pembesaran 1000x. Penelitian menggunakan Rancangan Acak Lengkap (RAL). Data yang diperoleh dianalisis dengan Independent Samples T-Test. Hasil penelitian menunjukkan ketinggian lokasi pemeliharaan (dataran tinggi dan rendah) berpengaruh terhadap neutrofil, namun tidak berpengaruh terhadap eosinofil dan basofil. Persentase neutrofil sapi bali di dataran tinggi lebih rendah dibandingkan di dataran rendah.
\end{abstract}

Kata kunci: sapi bali; diferensial granulosit; tipe dataran

\begin{abstract}
The aim of this study is to determine the differential granulocytes performed on neutrophils, eosinophils, and basophils in bali cattle which are raised in the highlands and lowlands in Nusa Penida. Blood samples were taken from 60 female bali cattle. Bali cattle blood sample was done randomly using multi-stage sampling. Blood collection was done through a jugular vein using a venoject. Blood smear was done using slide technique immediately, followed by fixation and sample staining using Giemsa. Differential leucocytes were counted using battlement method until 100 cells was found using 1000x magnification. Completely randomized design (CRD) was used for data analysis. The obtained data were analyzed with Independent Samples T-Test. The results showed that a type of maintenance location (highlands and lowlands) had a significant effect on neutrophil, but has not significant effect to eosinophils and basophils. The percentage of bali cattle neutrophils in the highlands is lower than in the lowlands.
\end{abstract}

Keywords: bali cattle; granulocytes differential; type of lands

\section{PENDAHULUAN}

Pulau Nusa Penida berada di Kecamatan Nusa Penida, Kabupaten Klungkung, Provinsi Bali. Pulau Nusa Penida terpisah dengan daratan Bali, yang lokasinya berdekatan dengan Pulau Nusa Ceningan dan Pulau Lembongan. Secara umum kondisi topografi Pulau Nusa Penida tergolong landai sampai berbukit. Di samping itu, Nusa Penida merupakan kawasan lahan kering dengan 2 musim yaitu kemarau dan hujan. Walaupun demikian sektor peternakan berkontribusi cukup besar terhadap total pendapatan masyarakat, terutama dari komoditas sapi bali (Muhammad, et al. 2012).

Pada tahun 2013 Menteri Pertanian melalui Dirjen Peternakan dan Kesehatan Hewan, menetapkan Nusa Penida sebagai wilayah pembibitan dan pemurnian sapi bali. Kemurnian genetiknya telah dilindungi dengan Peraturan Gubernur Bali Nomor 45 Tahun 2004 dan Perda No 2/2003 yang melarang bibit sapi bali betina 
keluar dari wilayah provinsi ini (Kasa, et al. 2015). Nusa Penida dianggap layak ditetapkan sebagai wilayah pembibitan dan pemurnian dikarenakan oleh beberapa hal seperti rasio populasi sapi bali antara betina dan jantan yang ideal yaitu 2,4:1 dan adanya barier/ penghalang alami berupa lautan sehingga mencegah penyebaran penyakit dari wilayah lainnya ke Nusa Penida ataupun sebaliknya (Hadi, 2002).

Hingga saat ini sapi bali dari wilayah Nusa Penida memiliki sistem pertahanan tuhuh yang lebih baik dibandingkan sapi bali di wilayah lainnya di Bali. Umumnya sapi bali di Bali rentan terserang penyakit Jembrana dan SE (Septicemia Epizootica) namun khusus sapi bali di Nusa Penida bebas terhadap penyakit tersebut (Suwiti, 2009). Bila dihubungkan dengan pertahanan ternak melawan penyakit, yang menjadi pertahanan tubuh secara internal adalah sistem imun. Sistem imun tersebut diperankan oleh sel darah putih/ leukosit (Turvey dan Broide, 2010).

Penelitian yang terkait dengan gambaran leukosit pada sapi bali hingga saat ini telah banyak dilakukan. Jumlah leukosit pada setiap spesies bervariasi dan dipengaruhi oleh keadaan tubuh individu tersebut. Beberapa faktor yang dapat mempengaruhi gambaran darah yaitu umur, jenis kelamin, bangsa (breed), penyakit, temperatur lingkungan, ketinggian lokasi, kebuntingan, kelahiran, kegiatan fisik, dan lain-lain (Hertaningsih, et al. 1983). Menurut Putra et al., (2016), persentase granulosit sapi bali yang dipelihara di lahan sawah menunjukkan neutrofil 24,33\%, eosinofil $3 \%$, dan basofil $0 \%$ sedangkan persentase di lahan tegalan menunjukkan neutrofil 20,3\%, eosinofil 2,3\%, dan basofil $0 \%$. Pada penelitian tersebut lahan sawah digolongkan dataran rendah sedangkan lahan tegalan digolongkan dataran tinggi.

Meskipun telah banyak dilakukan penelitian terkait gambaran ulas darah leukosit pada sapi bali, namun penelitian mengenai diferensial granulosit sapi bali di Nusa Penida berdasarkan tipe dataran/ ketinggian lokasi pemeliharaan belum pernah diteliti. Berdasarkan uraian tersebut perlu dilakukan penelitian dengan tujuan untuk mengetahui ada tidaknya perbedaan antara diferensial neutrofil, eosinofil, dan basofil sapi bali yang dipelihara di dataran tinggi dan rendah Nusa Penida.

\section{METODE PENELITIAN}

\section{Sampel Penelitian}

Penelitian ini menggunakan 60 ekor sapi bali berumur di atas 1 tahun yang semuanya berjenis kelamin betina. Sampel diambil dari dua desa di Kepulauan Nusa Penida. Desa Sekar Taji mewakili wilayah dataran tinggi dan Kutampi mewakili dataran rendah. Seluruh sapi bali yang dijadikan sampel dipastikan sehat secara klinis. Bahan yang digunakan adalah methanol, alkohol $70 \%$, Giemsa $10 \%$, aquades, dan minyak emersi. Peralatan yang digunakan adalah venoject, objek glass, kapas, stening jar, pipet pasteur, rak pewarnaan, gelas kimia, dan mikroskop (Pal dan Pal, 2005). Selanjutnya, pengamatan diferensial granulosit dilakukan di Laboratorium Histologi Fakultas Kedokteran Hewan Universitas Udayana.

\section{Metode Penelitian}

Menurut Zainuddin (1999) rancangan penelitian yang digunakan adalah Rancangan Acak Lengkap (RAL) dimana tipe dataran/ ketinggian lokasi pemeliharaan sebagai variabel bebas, gambaran diferensial granulosit (neutrofil, eosinofil, dan basofil) sebagai variabel terikat, dan darah sapi bali berjenis kelamin betina yang berumur di atas 1 tahun sebagai variabel kontrol. Jumlah sampel minimal ditentukan berdasarkan rumus:

$n=\frac{\mathrm{N}\left(\mathrm{Z}^{2}-\frac{\alpha}{2}\right) \mathrm{SD}^{2}}{(\mathrm{~N}-1) \mathrm{d}^{2}+\left(\mathrm{Z}^{2}-\frac{\alpha}{2}\right) \mathrm{SD}^{2}}$

Ket: $\mathrm{n}=$ besar sampel minimum; $\mathrm{N}=$ besar populasi; $Z^{2}-\alpha / 2=$ nilai distribusi normal baku (tabel Z) pada a tertentu; $\mathrm{SD}=$ standar deviasi; dan $\mathrm{d}=$ penyimpangan yang ditolerir. Bila diketahui : $\mathrm{SD}=1,01$ (Saragih, 2014), $Z^{2}-\alpha / 2=1,96, N=18.949$ 
(BPS Klungkung, 2013 dalam Saragih, 2014), $d=0,3$, maka:

$n=\frac{18.949 \times 1,96 \times 1,01^{2}}{(18.949-1) 0,3^{2}+1,96(1,01)^{2}}=21$.

Pengambilan sampel darah sapi bali dilakukan secara acak dimana digunakan multi-stage sampling dan dipilih masingmasing 30 ekor sapi bali yang mewakili dataran tinggi dan rendah di Nusa Penida. Spesimen darah di ambil dari vena jugularis dengan menggunakan venoject. Darah dalam venoject dikeluarkan dan diambil setetes darah yang kemudian ditaruh di ujung kaca objek dan segera dibuat sediaan ulasan darah (Utama, et al. 2013). Setelah dikeringkan dengan cara menganginanginkannya, sediaan ulas kemudian difiksasi menggunakan larutan methanol absolut selama lima menit. Objek glass dikeringkan dan diwarnai dengan metode pewarnaan Giemsa 10\% (Houwen, 2000). Takaran pewarnaan Giemsa adalah $1 \mathrm{ml}$ Giemsa ditambah dengan $9 \mathrm{ml}$ aquades sebagai pengencer dengan lama pewarnaan 15-20 menit. Setelah sediaan kering kemudian di simpan dan diamati di laboratorium menggunakan mikroskop dengan pembesaran 1000x dengan metode battlement hingga ditemukan 100 sel leukosit (Weiss dan Wardrop, 2010).

\section{Analisis Data}

Data yang diperoleh dianalisis dengan menggunakan analisis Independent Samples T-Test dengan menggunakan program software SPSS 17.0.

\section{HASIL DAN PEMBAHASAN}

\section{Hasil}

Hasil yang diperoleh dari penelitian diferensial granulosit sapi bali di dataran tinggi dan rendah Nusa Penida disajikan pada Tabel 1. Bila dibandingkan dengan nilai normal leukosit sapi bali, diferensial granulosit pada penelitian ini masih dalam taraf normal karena sapi bali betina yang digunakan sebagai sampel dalam keadaan sehat dan tidak menunjukkan gejala penyakit.
Menurut Marcolina (2009), perbedaan kondisi wilayah berdasarkan ketinggian tempat yaitu dataran tinggi dan rendah tidak menunjukkan perbedaan yang nyata terhadap jumlah granulosit sapi bali. Namun pada penelitian ini menunjukkan hasil yang berbeda. Berdasarkan uji Independent Samples T-Test, ketinggian lokasi pemeliharaan berpengaruh $(\mathrm{P}<0,05)$ terhadap neutrofil namun tidak berpengaruh $(\mathrm{P}>0,05)$ terhadap eosinofil dan basofil. Perbedaan hasil tersebut disebabkan pada jenis granulosit yang tidak dijabarkan secara rinci menjadi neutrofil, eosinofil, dan basofil.

Tabel 1. Persentase Granulosit Sapi Bali di Dataran Tinggi dan Rendah Nusa Penida

\begin{tabular}{cccc}
\hline Tipe & \multicolumn{3}{c}{ Persentase } \\
\cline { 2 - 4 } Dataran & Neutrofil & Eosinofil & Basofil \\
\hline Dataran & 20,43 & 4,23 & 0,33 \\
$\begin{array}{c}\text { Rendah } \\
\text { Dataran }\end{array}$ & 18,4 & 4,97 & 0,5 \\
$\begin{array}{c}\text { Tinggi } \\
\text { Rata- } \\
\text { rata }\end{array}$ & 19,4 & 4,6 & 0,4 \\
\hline
\end{tabular}

\section{Pembahasan}

Pada hasil penelitian yang dilakukan di dataran tinggi dan rendah Nusa Penida dapat dijelaskan jika persentase neutrofil dipengaruhi oleh ketinggian lokasi pemeliharaan dan temperatur lingkungan. Kemungkinan neutrofil lebih berperan dalam merespon perbedaan lingkungan antara di dataran tinggi dan rendah dibandingkan eosinofil dan basofil. Keadaan ini didukung oleh fungsi dari neutrofil itu sendiri dan respon neutrofil terhadap suhu lingkungan (Mashaly et al. 2004).

Bila diperhatikan dari segi fungsi, neutrofil memegang peran penting sebagai garis pertahanan pertama dalam melawan benda asing. Neutrofil akan mencerna benda asing tersebut kemudian akan mengalami autolisis dan melepaskan zatzat hasil degradasi ke dalam jaringan limfe (Lee et al. 2003). Jaringan limfe akan mengeluarkan histamin yang merangsang sumsum tulang melepaskan cadangan 
neutrofil sehingga produksi neutrofil akan meningkat (Lestari, et al. 2013).

Menurut Iskandar (2011) ketinggian tempat berhubungan dengan suhu. Semakin tinggi letak suatu daerah di atas permukaan laut maka akan semakin rendah suhu. Maka dari itu, dataran tinggi memiliki suhu yang rendah (bersuhu dingin) sementara dataran rendah memiliki suhu yang tinggi (bersuhu panas). Adanya perbedaan suhu lingkungan tersebut menjadikan setiap spesies hewan beradaptasi dengan mengatur keseimbangan panas tubuhnya. Keseimbangan panas tubuh ternak dapat dipengaruhi oleh kondisi internal dan eksternal. Kondisi eksternal yang menjadi kendala adalah suhu udara, kelembaban udara, dan radiasi matahari. Kondisi internal tubuh adalah proses-proses fisiologis berupa suhu rektal dan suhu kulit, termasuk proses metabolisme pakan (Suherman, 2014). Khusus pada penelitian ini hanya membahas pengaruh suhu udara yang dapat mengganggu keseimbangan panas tubuh ternak.

Menurut Brian et al., (2003) tidak ada perbedaan yang signifikan antara jumlah leukosit pada suhu panas ataupun dingin. Namun, menurut Mashaly et al., (2004) suhu yang tinggi dapat berdampak pada cekaman panas terhadap ternak. Pada penelitian ini pun persentase neutrofil meningkat pada suhu yang tinggi. Hal ini didukung dari tingginya suhu lingkungan di daerah tropis pada siang hari yang dapat mencapai $34^{\circ} \mathrm{C}$ dimana pada suhu tersebut dapat mengakibatkan penimbunan panas dalam tubuh, sehingga ternak mengalami cekaman panas. Stres (cekaman) panas adalah ketidakmampuan ternak menanggapi keadaan panas lingkungan yang bersuhu tinggi (Nawaan, 2006). Cekaman panas itu sendiri dapat mengganggu pembentukan sel-sel darah (eritrosit) dan produksi sel-sel imun (Sugito, et al. 2011).

Ternak yang mengalami cekaman panas akan membangun pertahanan diri. Salah satu bentuk adaptasi terhadap cekaman panas tersebut, tubuh akan memperbanyak jumlah leukosit atau menyebabkan terjadinya leukositosis. Hal ini disebabkan oleh peningkatan jumlah neutrofil (neutrofilia). Neutrofilia ini terjadi akibat adanya induksi glukokortikoid pada jalur pembentukan dan pelepasan neutrofil cadangan pada sumsum tulang (Blecha, 2000 dalam Sugito, et al. 2011).

Peningkatan persentase neutrofil di dataran rendah tidak berarti sapi bali di dataran rendah memiliki respon imun yang lebih baik terhadap infeksi bakteri karena hal tersebut perlu penelitian yang lebih mendalam. Peningkatan dan penurunan jumlah leukosit dapat terjadi karena pengaruh fisiologis dan/atau patologis. Leukositosis yang terjadi karena faktor fisiologis dapat disebabkan oleh aktivitas otot, rangsangan ketakutan, dan gangguan emosional. Sedangkan pengaruh patologis dapat disebabkan oleh agen infeksius yang menyerang tubuh (Ganong, 1999 dalam Triana dan Nurhidayat, 2006). Bila dihubungkan dengan suhu tinggi yang dapat menyebabkan cekaman panas, maka peningkatan persentase neutrofil di dataran rendah disebabkan karena faktor fisiologis. Hal ini diperkuat dari hasil penelitian yang menyatakan bahwa rata-rata neutrofil masih dalam kisaran normal. Nilai rujukan normal untuk persentase neutrofil sapi bali adalah $15-45 \%$, eosinofil $0-20 \%$, dan basofil 0-2\% (Pawitri, et al. 2014). Berdasarkan hal tersebut, peningkatan neutrofil akibat cekaman panas menjadi indikator suatu bentuk adaptasi sapi bali terhadap peningkatan suhu di luar comfort zone.

Setiap hewan mempunyai kisaran temperatur lingkungan yang paling sesuai yang disebut comfort zone. Pada sapi Brahman dapat hidup nyaman pada suhu $22-33^{\circ} \mathrm{C}$ dimana bila suhu di atas $33^{\circ} \mathrm{C}$ sapi Brahman dapat mengalami cekaman panas. Pada kerbau, comfort zone pada suhu antara $16-24^{\circ} \mathrm{C}$ dengan batas toleransi maksimal $27,6^{\circ} \mathrm{C}$ (Bamualim, et al. 2008). Bila dibandingkan dengan sapi-sapi dari daerah sub-tropis, sapi-sapi di daerah tropis memiliki daya tahan panas lebih tinggi 
seperti sapi bali dan madura (Warsono dan Mu'in, 2008). Meskipun sapi bali lebih tahan terhadap suhu panas, namun pemanasan global telah memicu terjadinya perubahan iklim bumi sehingga mempengaruhi terjadinya kenaikan temperatur di permukaan bumi. Dampak panas global (global warming) menyebabkan keadaan suhu di permukaan bumi cenderung terus meningkat (Lendrum dan Woodruff, 2006). Peningkatan suhu lingkungan ini mendorong meningkatnya kasus stres (cekaman) karena panas (heat stress) pada ternak (Mashaly, et al. 2004). Berdasarkan faktor perubahan iklim dunia yang kini semakin meningkatkan suhu lingkungan maka tidak menutup kemungkinan cekaman panas juga dirasakan oleh sapi bali.

\section{SIMPULAN DAN SARAN}

\section{Simpulan}

Persentase neutrofil sapi bali di Nusa Penida yang dipelihara di dataran tinggi lebih rendah dibandingkan di dataran rendah, sedangkan persentase eosinofil dan basofil tidak berbeda.

\section{Saran}

Diharapkan bagi peternak di dataran rendah untuk menggembalakan ternaknya di tempat yang rindang dengan tujuan untuk menekan pengaruh suhu panas pada siang hari yang dapat menyebabkan kejadian stres pada ternak.

\section{UCAPAN TERIMAKASIH}

Penulis mengucapkan terimakasih kepada seluruh pegawai Puskeswan (Pusat Kesehatan Hewan) Nusa Penida serta tim Monitoring dan Surveillance dari BBVet (Balai Besar Veteriner) Denpasar yang telah mendampingi dalam proses pengambilan sampel di Nusa Penida.

\section{DAFTAR PUSTAKA}

Bamualim A, Muhammad Z, Talib C. 2008. Peran dan ketersedian teknologi pengembangan kerbau di Indonesia. Seminar dan Lokakarya Nasional Usaha Ternak Kerbau Pp: 1-10.
Brian K, McFarlin, Joel BM. 2003. Exercise in hot and cold environments: differential effects on leukocyte number and NK cell activity. Aviation, Space, and Environ. Med. 74(12): 1231-1236.

Hadi PU. 2002. Problem dan prospek pengembangan usaha pembibitan sapi potong di indonesia. J. Litbang Pertanian. 21(4): 18-157.

Hertaningsih N, Sudana G, Malole MBM. 1983. The blood picture of bali cattle in Bali. Hemera Zoa Indon. J. Anim. Sci. 71(2): 155-160.

Houwen B. 2000. Blood film preparation and staining procedures. Lab. Hematol. 6: $1-7$.

Iskandar. 2011. Performan reproduksi sapi PO pada dataran rendah dan dataran tinggi di Provinsi Jambi. J. Ilmiah IlmuIlmu Peternakan. 14(1): 51-61.

Kasa IW, Sukmaningsih AAS, Darmayasa IB. 2015. Efforts in conserving purebred bali cattle as draught and beef type in Bali Island, Indonesia. Bul. Vet. Udayana. 7(1): 95-100.

Lee WL, Harrison RE, Grinstein S. 2003. Phagocytosis by neutrophils. Microb. Infect. 5:1299-1306.

Lendrum DC, Woodruff R. 2006. Comparative risk assessment of the burden of disease from climate change. Environ. Health Perspect. 114: 19351941.

Lestari SHA, Ismoyowati, Indradji M. 2013. Kajian jumlah leukosit dan diferensial leukosit pada berbagai jenis itik lokal betina yang pakannya di suplementasi probiotik. J. Ilmiah Peternakan. 1(2): 699-709.

Marcolina KN. 2009. Profil sel darah putih sapi bali. Skripsi. Fakultas Kedokteran Hewan, Universitas Udayana, Denpasar.

Mashaly MM, Hendrricks GL, Kalam MA, Gerhad AE, Abbas AO, Pattersom PH. 2004. Effect of heat stress on production parameters and immune responses of commercial laying hens. Poult. Sci. 83(6): 889-894. 
Muhammad Z, Puja IK, Wandia IN. 2012. Polimorfisme lokus mikrosatelit RM185 sapi bali di Nusa Penida. Indon. Med. Vet. 1(4): 505-518.

Nawaan S. 2006. Daya tahan panas pada Sapi Peranakan Simmental, Peranakan Ongole dan Sapi Pesisir. J. Peternakan Indonesia. 11(2): 158-166.

Pawitri NLPS, Dwinata IM, Dharmawan NS. 2014. Total dan diferensial leukosit sapi bali yang terinfeksi cysticercus bovis secara eksperimental. Indon. Med. Vet. 3: 213-222.

Putra IPC, Suwiti NK, Ardana IBK. 2016. Suplementasi mineral pada pakan sapi bali terhadap diferensial leukosit di empat tipe lahan. Bul. Vet. Udayana. 8(1): 8-16.

Saragih CI. 2014. Profil hormon pertumbuhan sapi bali di Kecamatan Nusa Penida Kabupaten Klungkung Provinsi Bali. M.Sc. Thesis. Universitas Udayana. Denpasar.

Sugito, Fakhrurrazi, dan Isa M. 2011. Efek pemberian ekstrak jaloh dikombinasi dengan probiotik dan kromium terhadap profil hematologi dan titer antibodi vaksin ND pada ayam broiler yang mengalami stres panas. Agripet. 11(2): 8-15.

Suherman D. 2014. Efek waktu pemberian pakan dan level energi terhadap cekaman panas berdasarkan suhu rektal dan kulit sapi dara Fries Holland. $J$. Sain Peternakan Indon. 9(2): 117-129.

Suwiti NK. 2009. Fenomena jembrana disease dan bovine immunodeficiency virus pada sapi bali. Bul. Vet. Udayana. 1(1): 21-25.

Triana E dan Nurhidayat N. 2006. Pengaruh pemberian beras yang difermentasi oleh Monascus purpureus Jmba terhadap darah tikus putih (Rattus Sp.) hiperkolesterolemia. J. Biol. Divers. 7(4): 317-321.

Turvey SE, Broide DH. 2010. Innate immunity. J. Allergy. Clin. Immunol. 125(2): 24-32.

Utama IH, Kendran AAS, Widyastuti SK, Virgania P, Sene SM, Kusuma WD, dan Arisandi BY. 2013. Hitung diferensial dan kelainan-kelainan sel darah sapi bali. J. Vet. 14(4): 462-466.

Warsono IU, Mu'in MA. 2008. Daya tahan panas sapi bali di Kabupaten Manokwari. J. Ilmu Peternakan. 3(1): 20-23.

Weiss DJ, Wardrop KJ. 2010. Schalm's veterinary hematology $6^{\text {th }}$ ed. Blackwell Publishing Ltd. Singapore.

Zainudin M. 1999. Metodologi Penelitian. Unair Press. Surabaya. 